\title{
5: 104384909-104370180
}

National Cancer Institute

\section{Source}

National Cancer Institute. 5: 104384909-104370180. NCI Thesaurus. Code C41827.

Physical location of CASP5_Gene 